\title{
Mining Site Reclamation Planning Based on Land Suitability Analysis and Ecosystem Services Evaluation: A Case Study in Liaoning Province, China
}

\author{
Jiali Wang ${ }^{1,2}$, Fuqiang Zhao ${ }^{1}$, Jian Yang ${ }^{1,3, *}$ and Xiaoshu $\mathrm{Li}^{3}$ \\ 1 Institute of Applied Ecology, Chinese Academy of Sciences, Shenyang 110016, China; \\ wangjiali833666@163.com (J.W.); zhaofuqiang@iae.ac.cn (F.Z.) \\ 2 University of Chinese Academy of Sciences, Beijing 100049, China \\ 3 Department of Forestry, University of Kentucky, Lexington, KY 40546, USA; xiaoshu.li@uky.edu \\ * Correspondence: jian.yang@uky.edu; Tel.: +1-859-257-7596
}

Academic Editor: Marc A. Rosen

Received: 28 March 2017; Accepted: 21 May 2017; Published: 26 May 2017

\begin{abstract}
Restoration of the degraded ecosystem is a global priority for achieving sustainable development. Although increasing ecosystem service is an important goal of ecological restoration, it is rarely used to inform mine reclamation. This study proposed a reclamation strategy that incorporated land suitability analysis and ecosystem service evaluation for a mining site in Liaoning Province, China. We assessed the land suitability for three reclamation alternatives and identified suitable land uses for each location by comparing their suitability levels. For areas that were suitable for multiple land uses with the same suitability level, the future land uses cannot be identified by land suitability analysis alone, and we employed ecosystem services evaluation to determine the optimal reclamation strategy. The results showed that forest could be restored throughout the entire mining site, agricultural land were most suitable in the western and southern parts, and developed land were in northern parts that were closer to roads and city centers. Our study showed that a large mining site can be reclaimed to different land uses and provided a practical framework for integrating ecosystem services into mine reclamation.
\end{abstract}

Keywords: mining site reclamation planning; land suitability analysis; ecosystem service; ecosystem service provision unit; China

\section{Introduction}

Ecological restoration is widely used to reverse the environmental degradation and mitigate human pressures on natural ecosystems [1,2]. Human activities have caused serious environmental deterioration across the world in the past decades. Surface mining is one of the most intensive human disturbances that negatively impacts the environment and human health [3]. It degrades ecosystem functions because it removes vegetation, alters the hydrological cycle and soil conditions, disrupts fundamental ecological relationships, and reduces biodiversity [4]. Furthermore, surface mining causes serious pollution to the air, water and soil. These negative impacts pose serious threats to human health. For example, it has been found that the incidence of chronic pulmonary disorders, hypertension, lung cancer and kidney disease were higher around mining sites [5]. Mining activity also produces a large amount of waste rocks and tailings, which pile up on the surface and occupy relatively large areas of land [6], reducing land use availability and increasing pressure on land supply.

Many countries have conducted ecological restoration programs to recover the damaged ecosystems in post-mining sites [7-9]. Most mine reclamation projects have laid emphasis on 
engineering design. A series of engineering measures have been adopted to restore damaged ecosystems in mining sites, including restructuring landforms, importing soil, and revegetation [10-12]. Reclamation of the abandoned mined land is a complex procedure, involving many ecological processes. For example, soil remediation includes the management of all types of physical, chemical and biological processes of soils, such as soil $\mathrm{pH}$, fertility, microbial community and various soil nutrient cycles [13]. In addition to the engineering measures, reclamation planning is also an essential component of its ecological restoration. The abandoned mined land could be reused or redeveloped into various land uses such as parks, residential areas and agricultural lands. The proper future land use types should be identified based on the suitability of local site conditions.

Land suitability analysis is the foundation for establishment of a mined land reclamation planning [14]. Numerous studies have selected the optimal post-mining land use types based on land suitability analysis $[15,16]$. Many factors are considered when measuring the suitability level for possible land reclamation alternatives, including topography, climate, and socioeconomic conditions. A large area of reclaimed land can be redeveloped to many different land uses when the heterogeneous environmental conditions within a mining site are considered. For example, some parts of a mining site close to roads and city centers may be better to be redeveloped into industrial and commercial site or residential area, while some parts with unfavorable topographic condition can only be restored to forest.

Land suitability analysis can help to identify possible suitable land uses for each location in a mining site. However, some locations may be appropriate for multiple land uses with the same suitability level. Land uses are exclusionary, and only one type can be allocated to each location [17]. The optimal land use cannot be determined solely based on the land suitability analysis in this circumstance. Other methods need to be applied to further refine the reclamation planning process. Governments and decision makers increasingly recognize the importance of integrating ecosystem services into ecological restoration and landscape planning [18-20]. The concept of ecosystem services was often used to assess the benefits from ecological restoration [21,22], but has seldom been applied to guide ecological restoration planning, especially for mining site reclamation. The mismatched scale is one of the reasons that limited the process of integrating ecosystem services into landscape planning and ecological restoration [23]. Mine reclamation is often conducted at a small extent, which ranges from a few hectares to several square kilometers. By contrast, studies of ecosystem services evaluation usually operate at broad extents, ranging from ecosystems, to landscape, regional and global scales [24-28]. Establishment of an interface between different spatial scales, which will be used not only as the basic unit of the ecosystem services evaluation, but also as the unit of mine reclamation planning, is critical to integrate the concept of ecosystem services into mining site reclamation planning at the small extent.

There are large differences in the provision of ecosystem services among various mine restoration alternatives. The results of ecosystem services evaluation present a benchmark to make comparisons among different reclamation alternatives and to identify which one would provide the maximum ecosystem service provision. Incorporating ecosystem service evaluation together with land suitability analysis would provide a comprehensive analysis for land reclamation planning of mining sites, through which we can not only determine whether the post-mining site can be successfully restored to certain land use types, but also show the potential ecological and economic benefits generated after restoration of the mined land.

In our study, we propose a way to design ecological restoration strategy based on land suitability analysis and ecosystem service evaluation for an iron ore mining site in Liaoning Province, China. First, we assessed the land suitability of three reclamation alternatives, forest land, agricultural land and developed land using the grey relational analysis [29]. Then, we analyzed the impacts of topographic factors on the spatial variability of ecosystem services using the concept of ecosystem service provision unit and evaluated the ecosystem services provided by reclaimed land under different reclamation alternatives. The optimal post-mining land uses were determined based on the results of land suitability 
analysis and ecosystem services evaluation. Our study shows a large mining site can be reclaimed to different land use types and proposes a useful method for integrating ecosystem services into mine reclamation.

\section{Study Area}

The study area is located in the central part of Liaoning Province in China $\left(41^{\circ} 27^{\prime}-41^{\circ} 31^{\prime} \mathrm{N}\right.$, $123^{\circ} 35^{\prime}-123^{\circ} 38^{\prime} \mathrm{E}$ ) and covers an area of 1337 hectares. The boundary of this mining site was manually digitized based on the aerial image (Figure 1). The topographic condition of this site has been changed dramatically by long-term surfacing mining activity. Based on ASTER Global Digital Elevation Model (DEM) (http:/ / www.gscloud.cn/) data, the elevation of the mining site ranges from 27 to $326 \mathrm{~m}$ above sea level. The slope in the mining site is quite steep, with the maximum value of the slope reaching approximately $50^{\circ}$. The study area is located in the town of Waitoushan, whose population is about 24,000 . There are many railways and asphalted roads in the mining site, which connect with the main road network of Liaoning province.

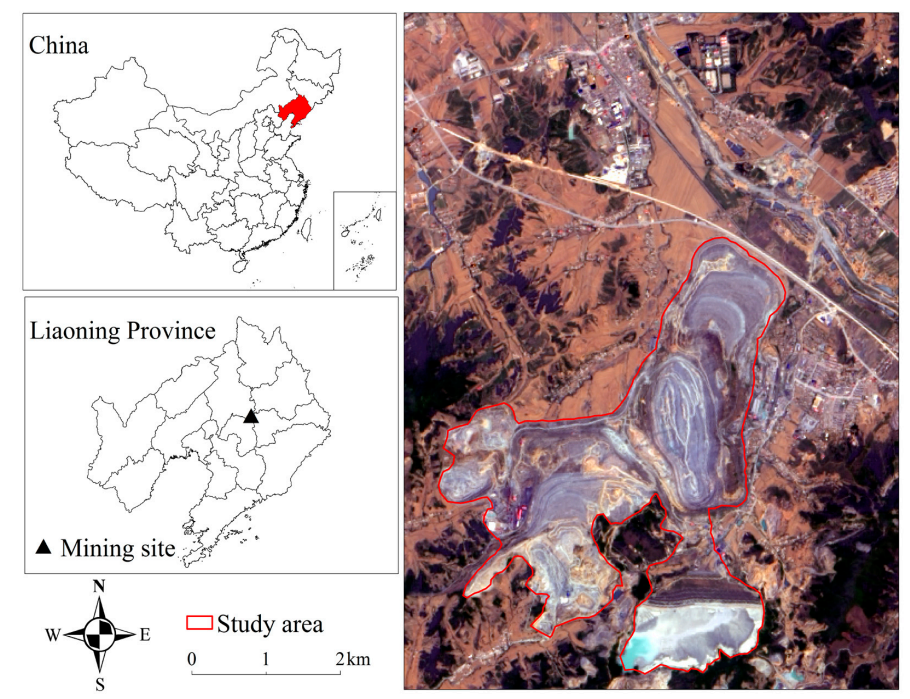

Figure 1. Location of the study area in Liaoning Province, China.

The study area has a great amount of iron ore resources, which have been exploited for more than 100 years. The mining industry is the backbone of the local economy and has made great contributions to the economic development of Liaoning Province. However, the study area is located in a critical transition zone between mountains and plains [30], which has a relatively vulnerable ecological environment. The ecosystem there has suffered serious degradation under the long-term mining activity. A great deal of dust and poisonous gas has been produced in the process of mining exploitation and transportation, causing seriously air pollution. Mining wastewater contains large amounts of contaminant, some of which have been discharged into river without advanced treatment, resulting in water pollution. Surfacing mining activity removes vegetation, strips topsoil, and the soil has been compacted due to the use of heavy machinery, which reduces infiltration capacity and promotes runoff by overland flow and increases frequency and magnitude of flooding [5]. Moreover, this mining site is close to city. For example, the distance to the biggest city of Liaoning Province is only $35 \mathrm{~km}$. There are large tracts of agricultural land and residential areas around the mining site. The rapid urbanization and population growth around the study area need more land to meet the demands of city expansion and an adequate food supply. It is necessary to propose a mine reclamation strategy from the perspective of redevelopment of the damaged mined land, not just natural conservation only. Therefore, we selected this mining site as our study area to plan various reclamation alternatives for supporting long-term sustainable development. 


\section{Materials and Methods}

\subsection{Land Suitability Analysis}

Land suitability analysis is a fundamental step in sustainable reclamation planning. Various types of reclamation alternatives could be adopted for post-mining land use, such as agricultural land, industrial areas, recreation areas, residential land and so on [31]. In this study, we will evaluate the land suitability for mine reclamation from three aspects: suitability for forest, agricultural land and developed land (which may be used as industrial areas, residential land, infrastructure for tourism development and so on).

An important part of land suitability analysis is to select the appropriate evaluation criteria. Topography, climate, and socioeconomic factors are often used to assess the suitability of mined land and other degraded ecosystems $[15,16]$. Slope is an important factor affecting land suitability. With the increase of slope steepness, the soil depth and soil fertility decrease, and the development of soils occurs more slowly [32]. The reclaimed soils on steep slopes in a mining site are more susceptible to erosion [33]. The relevant study showed that the slope with $0-2^{\circ}$ has been considered as highly suitable level, and greater than $8^{\circ}$ was treated as unsuitable level in agricultural land suitability analysis [33]. The areas with flat slope, lower elevation and lower relief amplitude (relative height difference between the highest and the lowest elevation within a neighborhood) are more likely to be reclaimed as agricultural land and developed land [34]. In the Northern Hemisphere, most plants exhibit optimum growth on the southern aspect, which receives more sunlight. The reclaimed land close to rivers, roads and city centers has higher potential for restoration to developed land. Therefore, we selected seven indicators from both natural and socioeconomic aspects in our study (Figure 2). Elevation, slope, aspect, relief amplitude and the distance to rivers were selected to represent natural factors. The socioeconomic factors included the distance to roads and the distance to city centers. Elevation, slope, aspect and relief amplitude data were derived from the ASTER Global Digital Elevation Model (DEM) with $30 \mathrm{~m}$ spatial resolution, which were provided by Geospatial Data Cloud site, Computer Network Information Center, Chinese Academy of Sciences (http:/ /www.gscloud.cn/). Distance to rivers, the distance to roads and the distance to city centers data were obtained using Euclidean distance analysis in AcrGIS9.3. All of the spatial data were converted into raster layers with $30 \mathrm{~m}$ spatial resolution. Classifying the study area into cells with size of $30 \mathrm{~m} \times 30 \mathrm{~m}$ would be helpful to analyze the heterogeneous conditions within a mining site because this moderate spatial resolution is consistent with many publicly available satellite products (e.g., DEM) that are widely used in the GIS analysis.

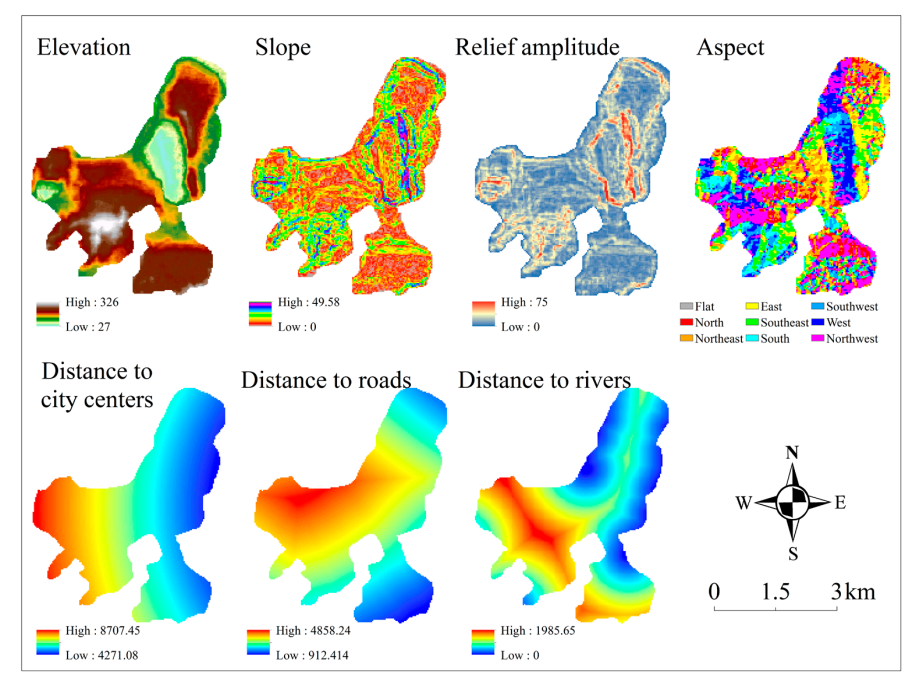

Figure 2. The evaluation factors of land suitability analysis. 
Grey relational analysis is a branch of grey system theory [35]. It has been used to make the optimal decision by analyzing the relationship between the evaluation values and reference values [36]. We used grey relational analysis to assess the suitability of mined land for reclamation to forest, agricultural land and developed land. Because the range and unit of one evaluation factor may differ from those of others, it is necessary to transform all of the evaluation factors into a comparable scale. This was achieved by a standardization process based on Equations (1) and (2) [37].

$$
\begin{aligned}
X_{i j}^{\prime} & =\frac{X_{i j}-X_{\min }}{X_{\max }-X_{\min }} \\
X_{i j}^{\prime} & =\frac{X_{\max }-X_{i j}}{X_{\max }-X_{\min }}
\end{aligned}
$$

Equation (1) is used for the attributes in which a higher value indicates better suitability. Equation (2) is used for the attributes in which a higher value suggests poorer suitability, where $X_{i j}^{\prime}$ represents the normalized value of the $j$ th evaluation factor in cell $i, X_{i j}$ is the value of the $j$ th evaluation factor in cell $i$, and $X_{\max }$ and $X_{\min }$ are the maximum and minimum values of the $j$ th evaluation factor, respectively.

The optimum values of these factors were considered as the reference values to calculate the degree of correlation between the optimum value and evaluation value. Because aspect is not a numerical variable, we assigned numerical values to the relevant categories according to their characteristics by the scoring method. In our study, the southward was regarded as the optimal aspect, which was assigned 9. The southwestern and southeastern, western and eastern, northwestern and northeastern, and northern were scored with 7, 5, 3, and 1, respectively. The related study has indicated that the areas with low elevation were more suitable for agricultural land, and the suitability level for crops will decline with an increase of elevation [38]. The elevation has less influence on the forest suitability, as there are still many trees at high altitudes. However, in the study of forest suitability analysis, it is generally considered that the areas with low altitude have high suitability level [39]. For slope and relief amplitude, lower values indicate higher suitability for all three reclamation alternatives; hence zero was regarded as the optimal value. Water is an important evaluation factor for agricultural land and forest suitability analysis. Surface water has been widely used to agricultural irrigation. The closer to the rivers, the more convenient the irrigation conditions are. Thus, we considered zero as the ideal optimal value for the factor of the distance to rivers in forest and agricultural land suitability analysis. Due to the progress of society, the factors of the distance to roads and the distance to city centers have less influence on the development of agriculture and forestry. These two factors were not considered in land suitability evaluation for forest and agricultural land. The areas close to city centers have a higher possibility of being restored to developed land. In contrast, the highest suitability level for developed land appeared at a certain proximity to the rivers and roads. Based on the related study and the local conditions [40], the zone of (500-1000 m) and (0-1000 m) were considered as the optimal zones of rivers and roads for developed land, respectively. The optimum values of each factor are shown in Table 1. The grey relational degree was calculated by Equation (3) [36]. The process mentioned above was accomplished using Raster Calculator in ArcGIS9.3. Taking the developed land suitability analysis as an example, the relational degree of each evaluation factor is shown in Figure 3.

$$
\xi_{i j}=\frac{\min _{i} \min _{j}\left|X_{j}^{*}-X_{i j}^{\prime}\right|+\rho \max _{i} \max _{j}\left|X_{j}^{*}-X_{i j}^{\prime}\right|}{\left|X_{j}^{*}-X_{i j}^{\prime}\right|+\rho \max _{i} \max _{j}\left|X_{j}^{*}-X_{i j}^{\prime}\right|}
$$

where $\xi_{i j}$ is the grey relational degree between evaluation indicator $j$ and its optimal value of the cell $i$; $X_{j}^{*}$ and $X_{i j}^{\prime}$ are the normalized results for the optimal value and the evaluation factor of indicator $j$, respectively; and $\rho$ is the distinguishing coefficient, and typically $\rho=0.5$. 
Table 1. The optimal values and weights for evaluation factors in land suitability analysis.

\begin{tabular}{ccccccc}
\hline \multirow{2}{*}{ Evaluation Factors } & \multicolumn{2}{c}{ Forest Suitability } & \multicolumn{2}{c}{ Agricultural Land Suitability } & \multicolumn{2}{c}{ Developed Land Suitability } \\
\cline { 2 - 7 } & Optimal Value & Weight & Optimal Value & Weight & Optimal Value & Weight \\
\hline Elevation $(\mathrm{m})$ & 0 & 0.1279 & 0 & 0.1301 & 0 & 0.0929 \\
Slope $\left(^{\circ}\right)$ & 0 & 0.2856 & 0 & 0.2659 & 0 & 0.2074 \\
Aspect & South $(9)$ & 0.1661 & South $(9)$ & 0.1677 & South (9) & 0.1206 \\
Relief amplitude $(\mathrm{m})$ & 0 & 0.2585 & 0 & 0.2417 & 0 & 0.1986 \\
The distance to rivers $(\mathrm{m})$ & 0 & 0.1619 & 0 & 0.1946 & $(500-1000)$ & 0.1189 \\
The distance to roads $(\mathrm{m})$ & - & - & - & - & $(0-1000)$ & 0.1497 \\
The distance to city & - & - & - & - & 0 & 0.1119 \\
centers $(\mathrm{m})$ & & & & & & \\
\hline
\end{tabular}

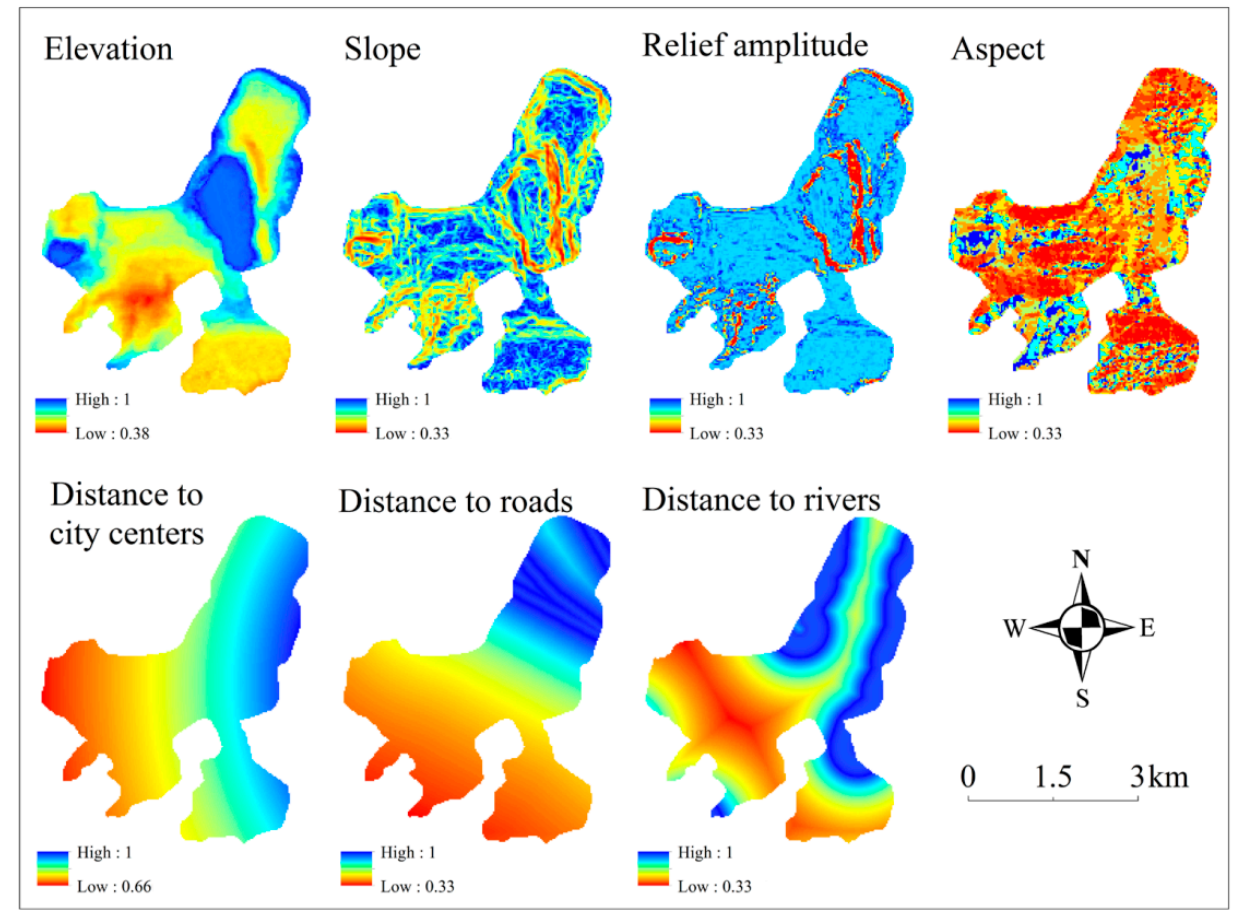

Figure 3. The grey relational degree of each evaluation factor for developed land suitability analysis.

Determination of the indicator weight is an important procedure for evaluating the mined land suitability for three reclamation alternatives. We employed the Analytic Hierarchy Process method (AHP) to determine the weights of the evaluation factors; the flow chart is illustrated in Figure 4. The first step of AHP is to establish a hierarchical model. The hierarchical model that consisted of objective level and factor level was created in our study. The objective level was land suitability for three reclamation alternatives, while the factor level was composed of the selected evaluation factors. The second step was to construct pair-wise comparison matrix. According to the advice of experts, including researchers, government officials and engineers with related background, we identified the relative importance of each factor using values ranging from 1 to 9 with intervals of 2, indicating equally important, slightly important, important, obviously important and extremely important, respectively [41]. The third step was to check the consistency of the pair-wise comparison matrix. If the consistency ratio (CR) was below 0.10 , it indicated that the judgment exhibited reasonable consistency. If the consistency ratio was above 0.10 , the judgments were considered inconsistent, and it should be improved [42]. The processes mentioned above were implemented using the Yaahp software [43]. The weights of evaluation factors are shown in Table 1. 


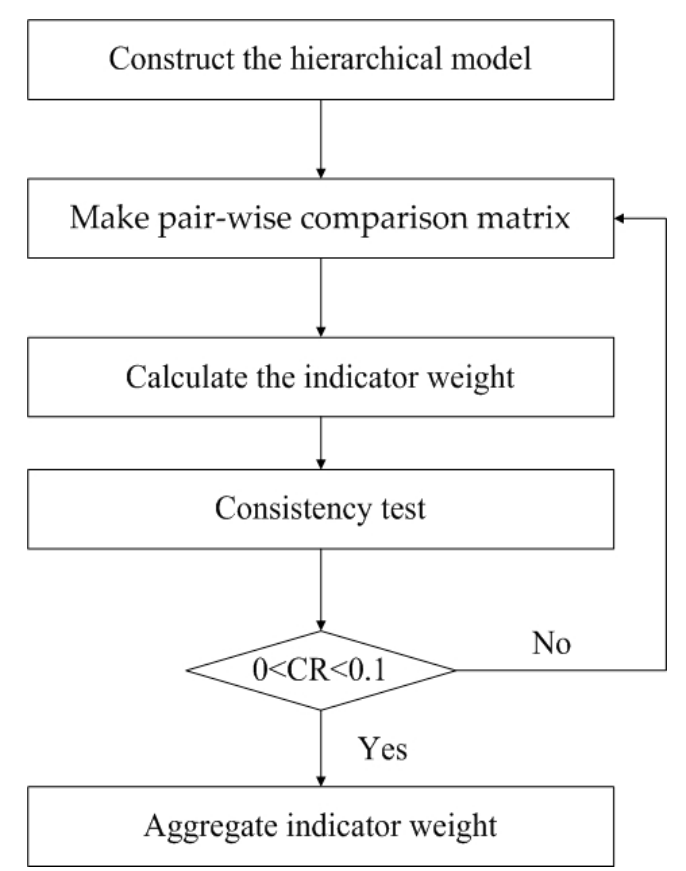

Figure 4. Flow chart of the Analytic Hierarchy process.

Land suitability analysis was conducted using the obtained grey relational degree of each evaluation factor multiplied by the relevant weight (Equation (4)).

$$
\operatorname{LSI}_{i}^{l}=\sum_{j=1}^{n} w_{j} \times \xi_{i j}
$$

where $L S I_{i}^{l}$ represents the value of land suitability for cell $i$ of the land use type $l ; l$ indicates three reclamation alternatives, which are forest, agricultural land and developed land; $w_{j}$ is the weight of the factor $j$; and $n$ is the number of evaluation factors.

Based on the results of land suitability analysis, the evaluation values were divided into four levels using the Natural Breaks (Jenks) method [44], which were deemed not suitable, marginally suitable, moderately suitable, and highly suitable. We assigned numeric values $1,2,3$, and 4 to the corresponding land suitability levels (from low level to high level), and then identified the most suitable land use type for every cell of the mining site by multi-suitability evaluation (Equation (5)). The results of multi-suitability evaluation were represented by three digit numbers. For example, 432 represented the cell was highly suitable for forest, moderately suitable for agricultural land, and marginally suitable for developed land; thus, the most suitable land use type for this cell was forest. However, some cells were suitable for multiple land use types with the same suitability level, and the future land use types cannot be identified by land suitability analysis alone. We employed ecosystem services evaluation to determine the optimal reclamation strategy under these circumstances.

$$
M L S=A \times 100+B \times 10+C
$$

where MLS is the result of multi-suitability evaluation; and $A, B$, and $C$ represented the suitability level of forest, farmland and developed land, respectively.

\subsection{Evaluation of Ecosystem Services}

The heterogeneity of environmental elements, including topographic factor, soil type and soil quality, can cause spatial variability of ecosystem services. A relevant study introduced the concept 
of ecosystem service provision unit (ESPU), which referred to an ecological complex with the similar ecosystem structure and environmental attributes that can provide the same magnitude of ecosystem services [45], to explore the spatial variation of ecosystem services. Topographic factors (especially slope) have great influence on ecosystem services provision. The productivity of agricultural land decreases significantly with the increase of slope. The spatial heterogeneity of slope also impacts on the water conservation and soil protection, as the related studies have shown that the forest located on steeper slopes can intercept larger amount of rainfall and provide greater soil protection services [45,46]. Slope is also an important factor affecting soil quality, the thickness of the soil layer and soil fertility generally decrease along the slope gradient [42], and the capacity of ecosystem to provide services has been directly affected. In our study, we considered slope as the most important factor affecting ecosystem service provision. We divided the study area into 4 ESPUs based on the slope and estimated the ecosystem services provided by the reclaimed land under different reclamation scenarios. The four slope categories were: flat slope (less than $5^{\circ}$ ), gentle slope (between $5^{\circ}$ and $15^{\circ}$ ), moderate slope (between $15^{\circ}$ and $25^{\circ}$ ), and steep slope (more than $25^{\circ}$ ). We assumed that developed land cannot provide any ecosystem services. Thus the ecosystem services provided by the reclaimed land under the scenarios of restoring the mined land to forest and agricultural land were estimated in our study. Furthermore, the areas with slope greater than $25^{\circ}$ cannot be used as agricultural land in our study, based on the guidelines of China's Grain for Green Project [47,48]. Therefore, there are 7 ecosystem service evaluation units in our study: forest on flat slope, agricultural land on flat slope, forest on gentle slope, agricultural land on gentle slope, forest on moderate slope, agricultural land on moderate slope, and forest on steep slope. We selected six types of ecosystem services that were closely related to the study area and estimated the economic value of each evaluation unit. A flow chart describing the detailed calculation process is illustrated in Figure 5.

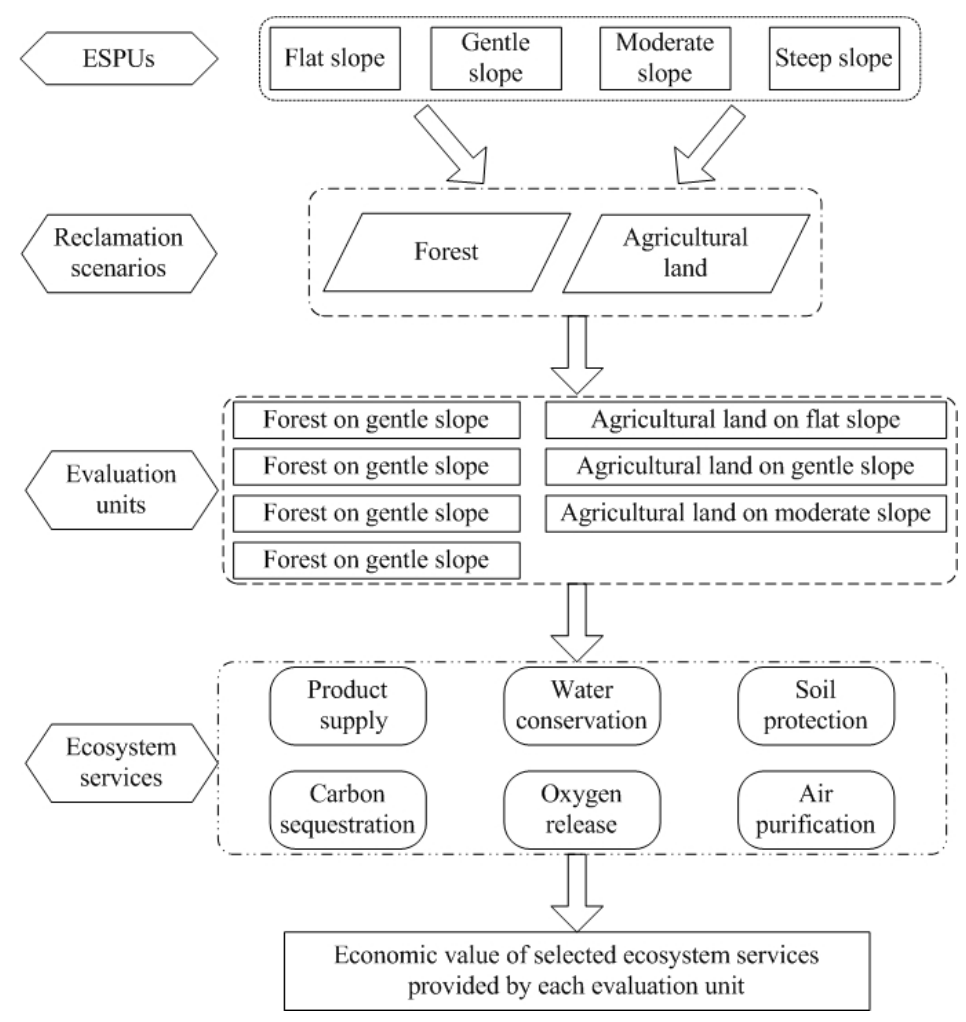

Figure 5. Flow chart of the ecosystem services evaluation.

The ecosystem services selected in our study were timber and agricultural production (provisioning services), water conservation, soil protection, carbon sequestration, oxygen release 
and air purification (regulating services). We evaluated the ecosystem services in monetary terms. Detailed information about the evaluation method is described below.

The economic value of timber and major agricultural products was calculated using a market price approach. The production information were derived from the Chinese forestry statistical yearbook [49] and Liaoning statistical yearbook (http://www.ln.stats.gov.cn/tjsj/sjcx/ndsj/). The monetary values of the related products were calculated based on the average of local market price.

The capacity of water conservation was measured by the difference between precipitation and potential evapotranspiration [50]. Annual average precipitation data were derived from Liaoning statistical yearbook, and potential evapotranspiration data were obtained from related study [51]. It has been shown that the amount of water conservation varies significantly due to different land cover types and topographical factors [46,52]. Based on a previous study [53], the coefficients that represented the different land cover types and various slope levels were employed to analyze the spatial heterogeneity of water conservation provided by each evaluation unit. The economic value was estimated by the cost of a new artificial reservoir. The process mentioned above was described by the following equation:

$$
E S_{w}=(P-E) \times S_{i} \times L_{j} \times C
$$

where $P$ represents annual average precipitation; $E$ is the potential evapotranspiration; $S_{i}$ and $L_{j}$ are the coefficients of the $i$ th slope class and the $j$ th land cover type, respectively; and $C$ is the cost of new reservoir for $1 \mathrm{~m}^{3}$ of water storage .

The amount of soil loss can be estimated by the difference between the potential erosion minus the actual erosion [52]. The amount of soil erosion was affected by various factors, such as climate, soil character, topography, and management. In our study, we assumed that the slope was the most important factor, because many other factors had little variation at the investigation scale. We used a slope coefficient to estimate the amount of soil protection of each evaluation unit, similar with the previous relevant research [45].

The capacity of soil protection was calculated using the following formula:

$$
S C=S_{i} \times\left(S E_{1}-S E_{2}\right)
$$

where $S C$ is the amount of soil protection; $S_{i}$ is the coefficient of the $i$ th slope class; and $S E_{1}$ and $S E_{2}$ represent potential soil erosion and actual soil erosion of forest and agricultural land, respectively. Soil erosion of forest and agricultural land values were derived from previous studies $[54,55]$.

The economic value of soil protection was estimated from three aspects: land abandonment, loss of soil fertility and river sedimentation. The economic value of abandoned land was estimated by the decreased values of timber and major agricultural products due to soil erosion. The market prices of nitrogen $(\mathrm{N})$, phosphate $(\mathrm{P})$ and potassium $(\mathrm{K})$ fertilizer were used to indicate the value of soil fertility loss. The cost of the new artificial reservoir was used to calculate the economic value of river sedimentation (Equations (8)-(10)).

$$
\begin{gathered}
E_{1}=S C \times B /(10000 \times h \times \rho) \\
E_{2}=\sum A\left(N_{S} C_{1} / R_{1}+P_{S} C_{2} / R_{2}+K_{S} C_{3} / R_{3}\right) \\
E_{3}=0.24 \times S C \times C / \rho
\end{gathered}
$$

where $E_{1}, E_{2}$, and $E_{3}$ are the economic values of the abandoned land, soil fertility loss and river sedimentation, respectively; $h$ and $\rho$ are the soil thickness and soil density, respectively; $B$ is the average market price of timber and major agricultural products; and $N_{s}, P_{s}, K_{s}, C_{1}, C_{2}, C_{3}, R_{1}, R_{2}$, and $R_{3}$ are the contents of $\mathrm{N}, \mathrm{P}$ and $\mathrm{K}$ in the soil, the prices of fertilizer containing $\mathrm{N}, \mathrm{P}$ and $\mathrm{K}$, and the contents of $\mathrm{N}, \mathrm{P}$ and $\mathrm{K}$ in the related fertilizers, respectively. The parameter values were derived from previous studies [55-57]. 
We calculated the amount of carbon sequestration and oxygen release based on photosynthesis, in which the production of $1 \mathrm{~kg}$ of dry matter can fix $1.63 \mathrm{~kg}$ of $\mathrm{CO}_{2}$ and release $1.19 \mathrm{~kg}$ of $\mathrm{O}_{2}[58,59]$. The economic value of carbon sequestration was estimated by the cost of afforestation in China. The value of oxygen release was evaluated by the cost of producing industrial oxygen. Vegetation can significantly improve air quality by removing pollutants, such as sulfur dioxide $\left(\mathrm{SO}_{2}\right)$, dust and other suspended particulates. The average annual absorption rates for $\mathrm{SO}_{2}$ and dust by forest and agricultural land and the economic value of contaminant treatment cost were derived from previous studies [60,61].

\section{Results}

\subsection{Land Suitability Analysis of Three Reclamation Alternatives}

The land suitability maps for three post-mining land use types (forest, agricultural land and developed land) are shown in Figure 6. The spatial distribution pattern of land suitability for the three reclamation alternatives exhibit a certain level of similarity. Except for the areas on steep slopes (more than $25^{\circ}$ ), the eastern portion of the mining site was classified as highly and moderately suitable levels for all three land uses. Most of the marginally suitable and not suitable areas were distributed in the western part of the mining site. The areas of moderately and marginally suitable regions were relatively large, accounting for $81.53 \%, 83.23 \%$ and $72 \%$ of study site for the three reclamation alternatives, respectively (Table 2). The area not suitable for forest was much smaller, indicating that most parts of the mining site can be reclaimed to forest. The result also showed that most evaluation units were suitable for more than one land use type. Some areas were characterized with the same suitability level, while other parts had different suitability levels. For instance, example location 1 was shown to be equally suitable for all the three reclamation alternatives. By contrast, example location 2 was shown to be highly suitable for forest and developed land, but only moderately suitable for agricultural land.

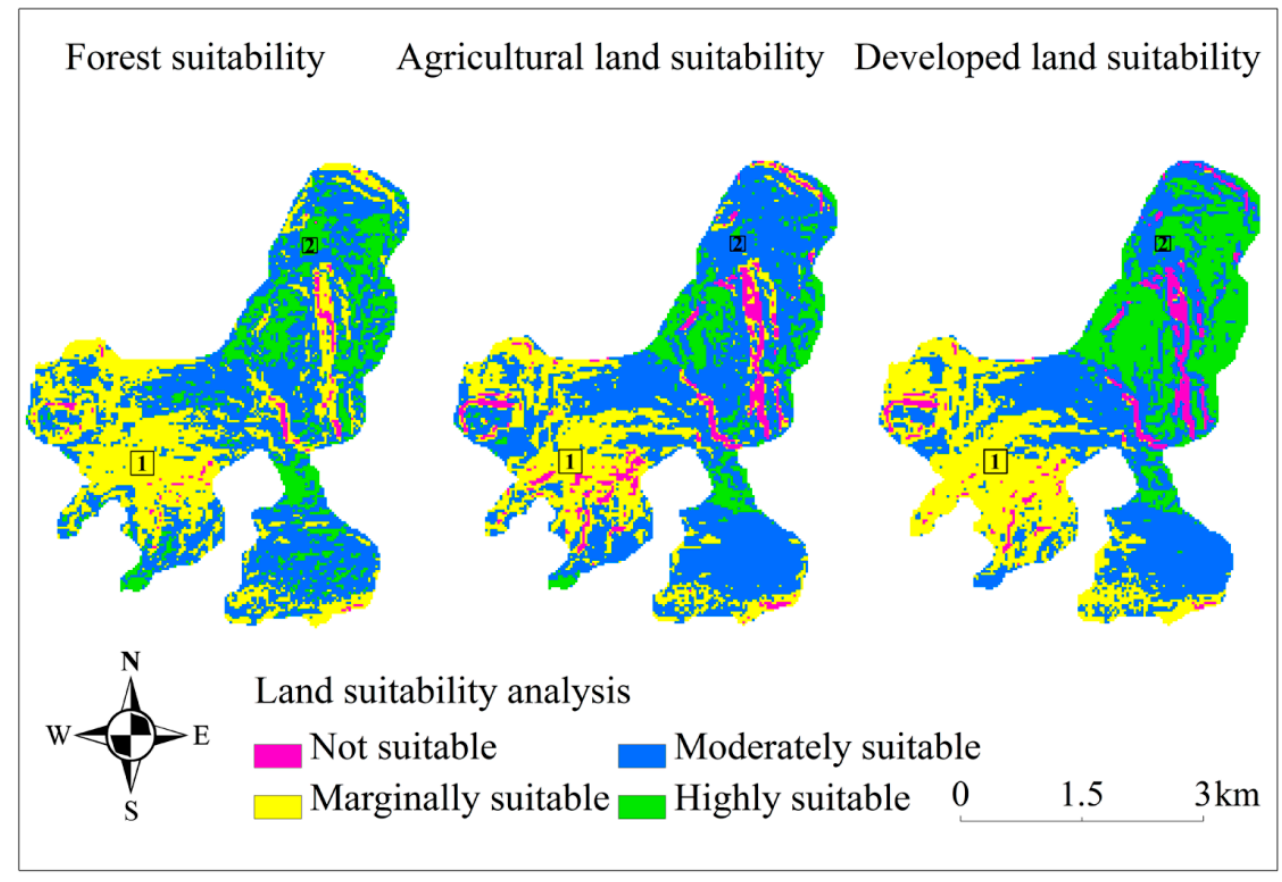

Figure 6. Land suitability distribution of the three reclamation alternatives. 
Table 2. Area and proportion of the different suitability levels.

\begin{tabular}{ccccccc}
\hline \multirow{2}{*}{ Land Suitability Level } & \multicolumn{2}{c}{ Forest Suitability } & \multicolumn{2}{c}{ Agricultural Land Suitability } & \multicolumn{2}{c}{ Developed Land Suitability } \\
\cline { 2 - 6 } & Area (ha) & Proportion (\%) & Area (ha) & Proportion (\%) & Area (ha) & Proportion (\%) \\
\hline Not suitable & 20.75 & 1.55 & 83.81 & 6.27 & 68.64 & 5.13 \\
Marginally suitable & 443.13 & 33.14 & 349.75 & 26.16 & 394.62 & 29.52 \\
Moderately suitable & 646.93 & 48.39 & 762.98 & 57.07 & 567.91 & 42.48 \\
Highly suitable & 226.19 & 16.92 & 140.46 & 10.51 & 305.83 & 22.87 \\
\hline
\end{tabular}

For areas whose suitability levels varied among the three reclamation alternative, we chose the one with the highest suitability level as the most suitable post-mining land use based on the multi-suitability evaluation (Figure 7). The results showed that areas in the northern part of the mining site could be used for developed land. The forest scattered throughout the study area, but its proportion was relatively small. Only a few cells located in the western part were suitable for agricultural land. However, most cells were equally suitable for multiple land use types, and their optimal reclamation strategy would be determined by the ecosystem service evaluation.

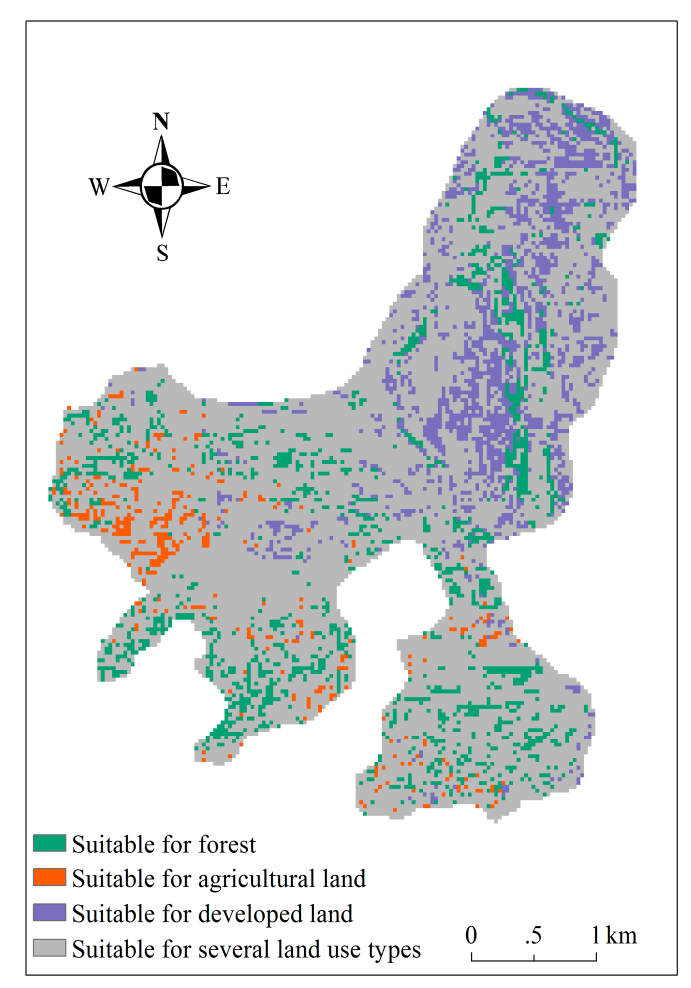

Figure 7. The suitable post-mining land use types.

\subsection{The Optimal Mining Site Reclamation Planning}

For the locations whose suitability level was the same for all three reclamation alternatives, we identified the optimal land use type based on the results of ecosystem services evaluation. The values of ecosystem services provided by each evaluation unit in different reclamation scenarios are illustrated in Figure 8. The results showed that the value of agricultural production was greater than timber, and the value of agricultural production decreased dramatically with the increase of slope. The water conservation value decreased significantly with slope increasing in both scenarios of restoring the mining site to forest and agricultural land. The value of soil conservation provided by forest was larger than that provided by agricultural land, which slowly increased with the increase of slope. For carbon sequestration and oxygen release, the net primary productivity of forest was not affected by slope, so the value provided by forest was the same in different evaluation units. The net 
primary productivity of agricultural land decreased with the increase of slope, thus the value offered by agricultural land reduced gradually. The value of air purification of forest and agricultural land was the same in different evaluation units.

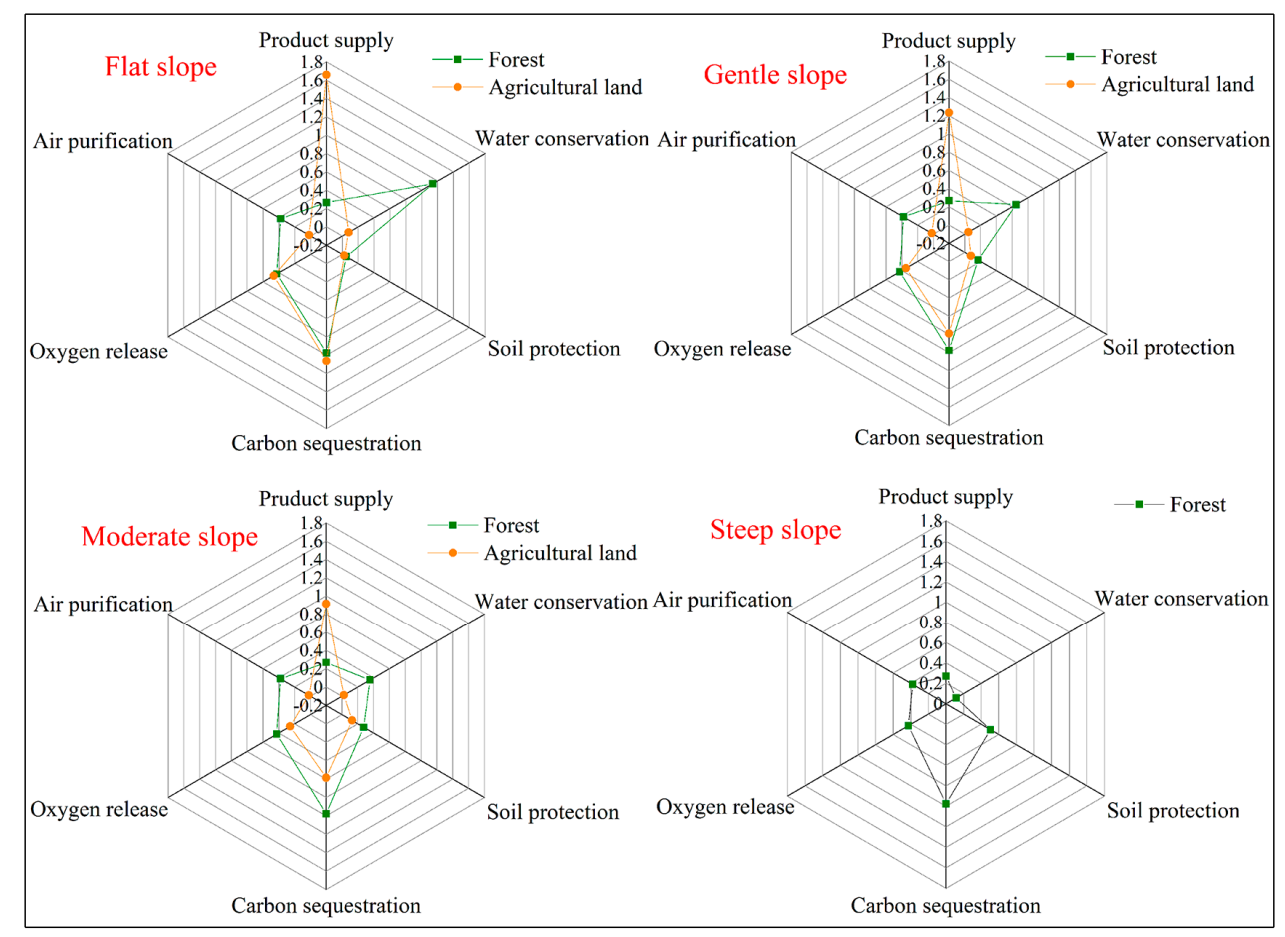

Figure 8. Economic value of ecosystem services provided by each ESPU in different reclamation scenarios ( $10^{4} \mathrm{RMB}$ per hectare) (RMB stands for Renminbi, which is the Chinese currency, at an exchange rate of US\$1.00 $=$ RMB6.86 as of March 2017).

The total economic value of ecosystem services provided by each ESPU is shown in Figure 9. The ecosystem services provided by forest and agricultural land decreased gradually as slope increases. The economic value provided by forest on moderate slopes and steep slopes did not exhibit significant differences. The economic value provided by agricultural land was more than that provided by forest on flat slopes $\left(0-5^{\circ}\right)$, which was opposite to that on other level of slopes. This result indicated that cells on flat slopes can be reclaimed to agricultural land and other areas on gentle, moderate slope and steep slope can be restored to forest to achieve maximum ecosystem service provision.

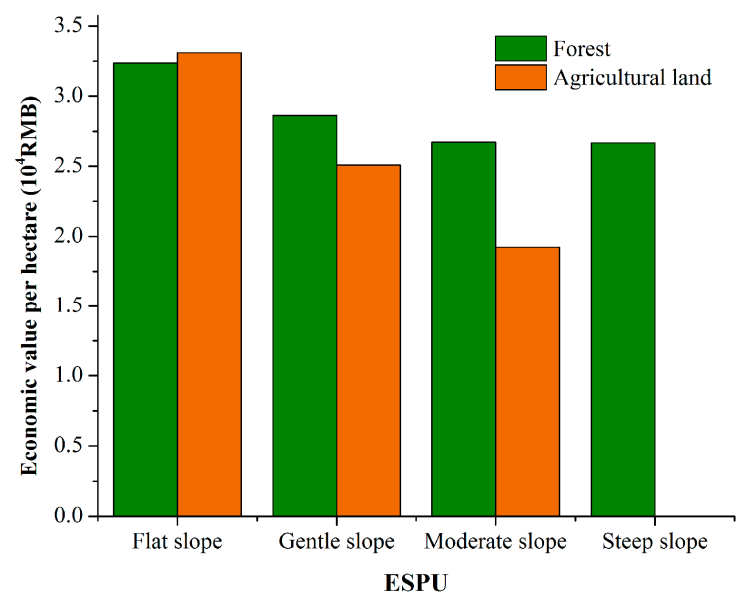

Figure 9. The total economic value of ecosystem services provided by each ESPU. 
Combining the results of land suitability analysis and ecosystem service evaluation, we identified the optimal land use type for each cell of the mining site (Figure 10b). Figure 10a showed the areas that moderately suitable for forest and agricultural land on flat slope, gentle slope and moderate slope. Comparing Figures 10a and 10b, we found that some cells that were moderately suitable for forest and agricultural land on flat slope were reclaimed to agricultural land based on the ecosystem services evaluation, while the cells with the same characteristics located on gentle and moderate slope were restored to forest. The result showed that most of the study area can be restored to forest, whose proportion reached nearly $67 \%$ of the whole area. Most agricultural lands were located in the western and southern parts on flat slope. The developed lands were distributed in the northern and central parts that were close to roads and city centers. The area of the developed land was relatively small, accounting for only $12 \%$ of the total area.

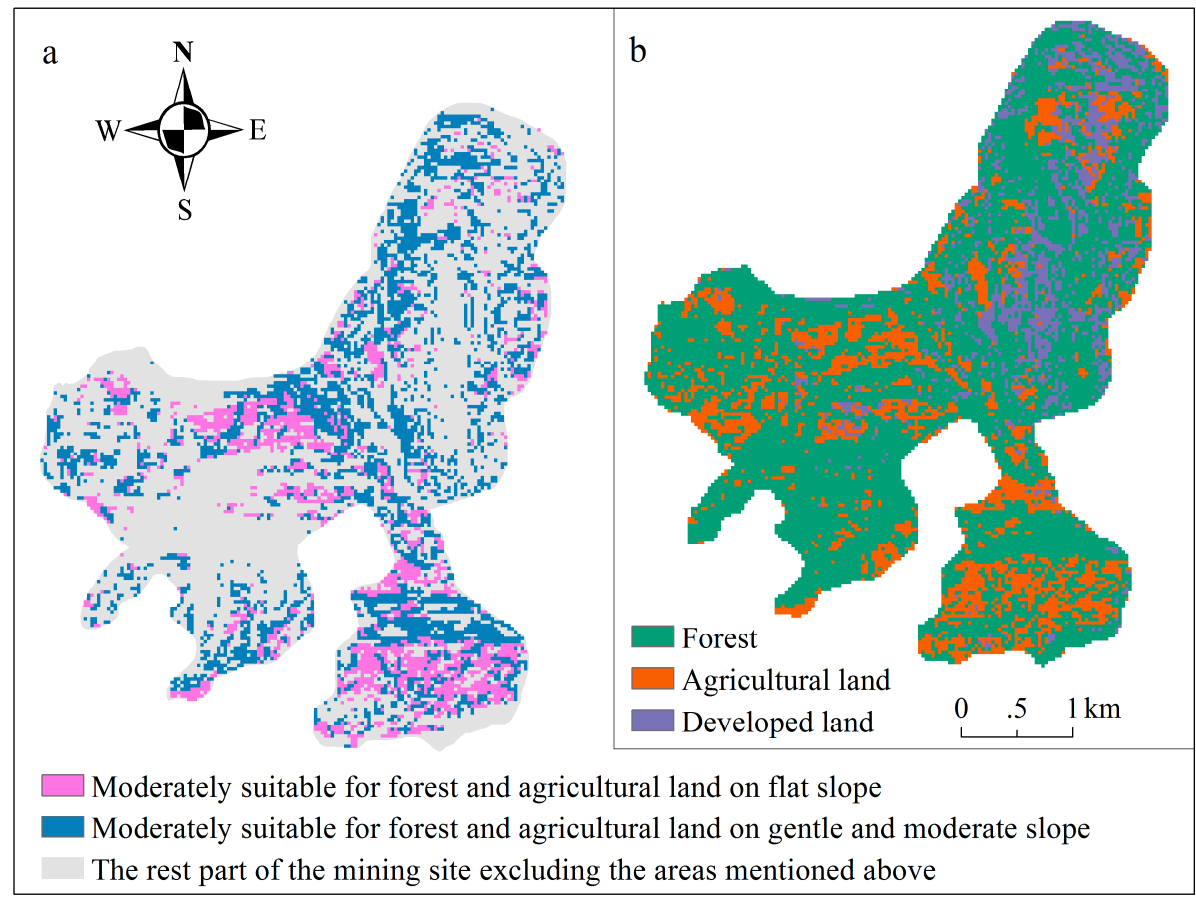

Figure 10. (a) The areas that moderately suitable for forest and agricultural land on flat slope, gentle slope and moderate slope; and (b) the optimal reclamation strategy for the mining site.

\section{Discussion}

\subsection{Integrating Ecosystem Services into Mine Reclamation}

There is a growing interest in investigating ecosystem services since the release of the Millennium Ecosystem Assessment [23]. The concept of ecosystem services has been widely applied in many international initiatives and related policy designs, such as The Economics of Ecosystems and Biodiversity (TEEB), European Union's Biodiversity Strategy, and European Union's Common Agriculture Policy [27]. However, the implementation of ecosystem services assessment in practical planning and decision-making are still in its infancy [62], especially in the mine reclamation projects. The concept of ecosystem services has been used to assess the benefit from ecological restoration projects of abandoned mining sites [21,63], but has rarely been used as a guideline for mine reclamation planning. It has been noted that increasing ecosystem service provision of reclaimed land should be treated as an important goal of ecological restoration [64]. Nevertheless, the land uses for the post-mining area are often determined based on the constraints of physical environment and the related environmental protection regulations [65], which were seldom identified for the purpose of maximizing the ecological service. 
The concept of ESPU was applied to bridge between ecosystem services evaluation and ecological restoration in a mining site. The magnitude of ecosystem services has been assessed by ecosystem type, neglecting the heterogeneity of environmental characteristics within each ecosystem type. However, the topographic factors, especially slope, can play an important role in driving the spatial variability of ecosystem services [32]. We divided the study area into four groups based on the slope steepness level and assessed the ecosystem services under different reclamation scenarios. The reclamation scenario with the maximum ecosystem services was identified for each slope steepness class, which will assist in allocating the optimal land uses for different parts of the mining site. The ESPU was not only used as the basic unit of the ecosystem services evaluation, but also as the unit of mine reclamation planning. By using the concept of ESPU, our study proposed a method for developing a linkage to connect the different scales of ecosystem services studies and land use planning, which will contribute to the integration of ecosystem services into mine reclamation planning at small scales.

Our ecosystem service evaluation results showed that the areas on flat slope $\left(0-5^{\circ}\right)$ provided more ecosystem services if they were reclaimed to agricultural land. By contrast, areas located on steeper slopes offered more ecosystem services if they were restored to forest. This was mainly driven by the general relationship between soil thickness/soil fertility and slope. The areas on flat slope were more productive to provide agricultural products; hence, we proposed to reclaim these areas to agricultural land. In contrast, areas on gentle, moderate, and steep slopes should be reclaimed to forest for the purpose of the maximum ecosystem service provision because forest located on steeper slope can offer more benefits for water conservation and erosion control than agricultural land. Our study showcases how the incorporation of ecosystem service can help to develop a master plan for mine reclamation.

\subsection{The Heterogeneirity of Future Land Use within a Mining Site}

The ecosystem services evaluation provided information about which reclamation scenarios can offer more benefits for human society. However, the reuse type with maximum ecosystem service provision may have a low suitability level for some parts of the study area. The future land uses of an abandoned mining site should first be identified based on the suitability of local site conditions. Due to the heterogeneity of the environmental and landscape characteristics, the reclamation scenarios may vary for different mining sites within a geographic area. For example, in the metropolitan area of Bari (Italy), there were ten quarries identified with different reclamation alternatives in response to natural factors and the relationship with surrounding areas [7]. Furthermore, the heterogeneous environment within a mining site can also affect the future land use type for a post-mining site. A large mining site can be reclaimed to a variety of land use types considering the heterogeneity of the site condition. Our study identified the optimal land uses at the cell level to investigate how the heterogeneous environment impacts on the distribution of suitable land use types at small scales. All of the evaluation criteria were presented by continuous information layers in raster format, and the results were illustrated by thematic maps, so that decision makers can explicitly identify the suitable locations for a given land use type [66]. Our results showed that most of the highly and moderately suitable areas were characterized with low elevation and gentle slope. The results indicated that topographic factors played a critical role in the land suitability analysis, which agrees with studies conducted at other mining sites [14]. The cells in the eastern and northern parts of the mining site were highly suitable for developed land since they were close to roads and city centers.

\subsection{Uncertainties Involved in the Land Suitability Analysis and Ecosystem Services}

It should be noted that the climate factors and soil conditions are the critical requirements for any ecological restoration planning. However, within a single mining site, despite its relatively large size, little variation of climatic conditions would exist. Thus, we did not take climatic variations into account in our study. Soil is an important factor in mining site restoration practices [67]. The productivity of the reclaimed grasslands and shrubs is often limited due to poor soil conditions [68]. In many surface mining sites, the topsoil soils are completely destroyed by mine exploitation. The related research has 
indicated that the mine soils composed of crushed overburden can provide a suitable soil substitute when native soil is unavailable for use in mine reclamation practice [69]. The suitable soil substitutes, such as weathered mine spoils, should be selected carefully by analyzing the characteristics of mine spoil. It is worthwhile to note that agricultural land is an important reclamation alternative for the damaged mined land. A previous study applied fuzzy multi-attribute decision-making to select the optimal reclamation land use for a surface coal mine, and its result showed that agricultural land was the optimal choice [31]. Some parts of a lignite mining site in west Macedonia, Northern Greece were suggested to be reclaimed into agricultural land [15]. Large economic benefits could be obtained if reclaimed to agricultural land. A related study showed that the economic benefit reached to 59 USD ha $^{-1}$ after 5-6 years forage crop reclamation in AnTaibao mine in Shanxi Province, China. If other crops such as naked oat, potato, and maize, were planted, the economic benefits could probably be higher [70]. There are large pieces of agricultural land and villages around the study area. It is expected a portion of this mining site will be more likely to be reclaimed to agricultural land to meet the demands of human beings driven by the economic interests. However, the waste rocks and tailings may contain heavy metals, which could pose a serious threat to food security and public health if reclaimed to agricultural land without any treatment measure. Appropriate engineering measures and reclamation techniques also should be conducted to treat the contamination of the waste rocks and tailings in mine reclamation practices.

Our study also did not consider the forestation success rate and crop productivity of the reclaimed land, which may affect the precision of the ecosystem services evaluation. Field experiments need to be conducted to investigate the productivity of reclaimed land in the future research. The developing soil and soil humus layers can absorb large amounts of carbon, which has been considered as an important carbon sink. However, we only calculated the carbon sequestration by living plants due to the limitation of data. Although our approach is relatively simple, it is straightforward and easy to apply, as the method is relatively easy to understand and the required data are freely and publicly available. In addition, the mining site could be considered to be of a special industrial heritage, which can be developed for tourism [71,72]. However, the main objective of our research was to identify the optimal future land uses for the post-mining area, and the protection of the mining heritage was beyond the scope of this study. Notwithstanding the limitation of the method and results, our study offered constructive insights to design a better reclamation planning to recover the damaged mined ecosystems.

\section{Conclusions}

Our study proposed a simple yet straightforward strategy for post-mining reclamation and applied it to an iron mining site located in the central part of Liaoning Province, China. We recognized the heterogeneous environment within the mining site and selected the optimal land use types by combining land suitability analysis and ecosystem service evaluation. The results of our land suitability analysis showed that most parts of the study area were suitable for multiple land use types. For locations with the same suitability level, we identified the optimal land uses based on the results of ecosystem services evaluation. The study area was divided into four groups based on the slope using the concept of ecosystem services provision unit (ESPU), which was considered to be the basic unit for ecosystem services evaluation. We assessed the ecosystem services of each ESPU under different reclamation scenarios and incorporated the impacts of the topographic factor on the spatial heterogeneity of ecosystem services provision into reclamation design. The reclamation scenario with the maximum ecosystem services provision was identified, which provided useful information for selecting optimal land uses alternatives for different parts of the mining site. This reclamation planning method can not only provide theoretical guidance for ecological restoration of post-mining areas, but also be used to restore other wastelands with similar contexts. 
Author Contributions: Jiali Wang, Jian Yang and Fuqiang Zhao conceived and designed the study; Jiali Wang and Fuqiang Zhao analyzed the data and interpreted the results; Jiali Wang wrote the manuscript; and Jian Yang and Xiaoshu Li revised and improved the manuscript.

Conflicts of Interest: The authors declare no conflict of interest.

\section{References}

1. Feng, X.; Fu, B.; Lu, N.; Zeng, Y.; Wu, B. How ecological restoration alters ecosystem services: An analysis of carbon sequestration in China's Loess Plateau. Sci. Rep. 2013, 3, 2846. [CrossRef] [PubMed]

2. Benayas, J.M.R.; Newton, A.C.; Diaz, A.; Bullock, J.M. Enhancement of biodiversity and ecosystem services by ecological restoration: A meta-analysis. Science 2009, 325, 1121-1124. [CrossRef] [PubMed]

3. Cao, X. Regulating mine land reclamation in developing countries: The case of China. Land Use Policy 2007, 24, 472-483. [CrossRef]

4. Li, F.; Liu, X.; Zhao, D.; Wang, B.; Jin, J.; Hu, D. Evaluating and modeling ecosystem service loss of coal mining: A case study of Mentougou District of Beijing, China. Ecol. Complex. 2011, 8, 139-143. [CrossRef]

5. Palmer, M.A.; Wilcock, P.R. Mountaintop mining consequences. Science 2010, 327, 148-149. [CrossRef] [PubMed]

6. Li, M.S. Ecological restoration of mineland with particular reference to the metalliferous mine wasteland in China: A review of research and practice. Sci. Total Environ. 2006, 357, 38-53. [CrossRef] [PubMed]

7. Dal, S.P.; Ottolino, M.A.; Caliandro, L.P. Identification of quarries rehabilitation scenarios: A case study within the Metropolitan area of Bari (Italy). Environ. Manag. 2012, 49, 1174-1191.

8. Zipper, C.E.; Burger, J.A.; Skousen, J.G.; Angel, P.N.; Barton, C.D.; Davis, V.; Franklin, J.A. Restoring forests and associated ecosystem services on Appalachian coal surface mines. Environ. Manag. 2011, 47, 751-765. [CrossRef] [PubMed]

9. Dulias, R. Landscape planning in areas of sand extraction in the Silesian upland, Poland. Landsc. Urban Plan. 2010, 95, 91-104. [CrossRef]

10. Gao, L.; Miao, Z.; Bai, Z.; Zhou, X.; Zhao, J.; Zhu, Y. A case study of ecological restoration at the Xiaoyi Bauxite mine, Shanxi Province, China. Ecol. Eng. 1998, 11, 221-229. [CrossRef]

11. Sklenička, P.; Lhota, T. Landscape heterogeneity-A quantitative criterion for landscape reconstruction. Landsc. Urban Plan. 2002, 58, 147-156. [CrossRef]

12. Wang, Y.; Dawson, R.; Han, D.; Peng, J.; Liu, Z.; Ding, Y. Landscape ecological planning and design of degraded mining land. Land Degrad. Dev. 2001, 12, 449-459. [CrossRef]

13. Sheoran, V.; Sheoran, A.S.; Poonia, P. Soil reclamation of abandoned mine land by revegetation: A review. Int. J. Soil Sediment Water 2010, 3, 1-20.

14. Wang, S.D.; Liu, C.H.; Zhang, H.B. Suitability evaluation for land reclamation in mining area: A case study of Gaoqiao Bauxite mine. Trans. Nonferrous Met. Soc. China 2011, 21, s506-s515. [CrossRef]

15. Pavloudakis, F.; Galetakis, M.; Roumpos, C. A spatial decision support system for the optimal environmental reclamation of open-pit coal mines in Greece. Int. J. Min. Reclam. Environ. 2009, 3, 291-303. [CrossRef]

16. Soltanmohammadi, H.; Osanloo, M.; Bazzazi, A.A. An analytical approach with a reliable logic and a ranking policy for post-mining land-use determination. Land Use Policy 2010, 27, 364-372. [CrossRef]

17. Mendoza, G.A. GIS-Based Multicriteria Approaches to Land Use Suitability Assessment and Allocation. In United States Department of Agriculture Forest Service General Technical Report NC; United States Department of Agriculture: Pennsylvania, PA, USA, 2000; pp. 89-94.

18. Arkema, K.K.; Verutes, G.M.; Wood, S.A.; Clarke-Samuels, C.; Rosado, S.; Canto, M.; Rosenthal, A.; Ruckelshaus, M.; Guannel, G.; Toft, J. Embedding ecosystem services in coastal planning leads to better outcomes for people and nature. Proc. Natl. Acad. Sci. USA 2015, 112, 7390-7395. [CrossRef] [PubMed]

19. Kabisch, N. Ecosystem service implementation and governance challenges in urban green space planning-The case of Berlin, Germany. Land Use Policy 2015, 42, 557-567. [CrossRef]

20. Prach, K.; Tolvanen, A. How can we restore biodiversity and ecosystem services in mining and industrial sites? Environ. Sci. Pollut. Res. 2016, 23, 1-4. [CrossRef] [PubMed]

21. Larondelle, N.; Haase, D. Valuing post-mining landscapes using an ecosystem services approach-An example from Germany. Ecol. Indic. 2012, 18, 567-574. [CrossRef] 
22. Liu, J.; Li, S.; Ouyang, Z.; Tam, C.; Chen, X. Ecological and socioeconomic effects of China's policies for ecosystem services. Proc. Natl. Acad. Sci. USA 2008, 105, 9477-9482. [CrossRef] [PubMed]

23. Groot, R.S.D.; Alkemade, R.; Braat, L.; Hein, L.; Willemen, L. Challenges in integrating the concept of ecosystem services and values in landscape planning, management and decision making. Ecol. Complex. 2010, 7, 260-272. [CrossRef]

24. Thompson, J.R.; Lambert, K.F.; Foster, D.R.; Broadbent, E.N.; Blumstein, M.; Almeyda Zambrano, A.M.; Fan, Y. The consequences of four land-use scenarios for forest ecosystems and the services they provide. Ecosphere 2016, 7, 1-22. [CrossRef]

25. Jra, B.; Wong, G.Y.; Metcalfe, D.J.; Honzák, M.; Pert, P.L.; Rao, N.; van Grieken, M.E.; Lawson, T.; Bruce, C.; Kroon, F.J. An analysis of trade-offs between multiple ecosystem services and stakeholders linked to land use and water quality management in the great barrier reef, Australia. Agric. Ecosyst. Environ. 2013, 180, 176-191.

26. Nelson, E.; Mendoza, G.; Regetz, J.; Polasky, S.; Tallis, H.; Cameron, D.; Chan, K.M.; Daily, G.C.; Goldstein, J.; Kareiva, P.M. Modeling multiple ecosystem services, biodiversity conservation, commodity production, and tradeoffs at landscape scales. Front. Ecol. Environ. 2009, 7, 4-11. [CrossRef]

27. Maes, J.; Egoh, B.; Willemen, L.; Liquete, C.; Vihervaara, P.; Schägner, J.P.; Grizzetti, B.; Drakou, E.G.; Notte, A.L.; Zulian, G. Mapping ecosystem services for policy support and decision making in the European Union. Ecosyst. Serv. 2012, 1, 31-39. [CrossRef]

28. Jia, X.; Fu, B.; Feng, X.; Hou, G.; Liu, Y.; Wang, X. The tradeoff and synergy between ecosystem services in the Grain-for-Green areas in northern Shaanxi, China. Ecol. Indic. 2014, 43, 103-113. [CrossRef]

29. Li, B.; Zhang, F.; Zhang, L.; Huang, J.; Jin, Z.; Gupta, D.K. Comprehensive suitability evaluation of tea crops using GIS and a modified land ecological suitability evaluation model. Pedosphere 2012, 22, 122-130. [CrossRef]

30. Xie, L. Suggestions for water environment management in Shenyang. Water Res. Hydropower Northeast China 2015, 33, 51-52. (In Chinese)

31. Masoumi, I.; Naraghi, S.; Rashidi-Nejad, F.; Masoumi, S. Application of fuzzy multi-attribute decision-making to select and to rank the post-mining land-use. Environ. Earth Sci. 2014, 72, 221-231. [CrossRef]

32. Koulouri, M.; Giourga, C. Land abandonment and slope gradient as key factors of soil erosion in Mediterranean terraced lands. Catena 2007, 69, 274-281. [CrossRef]

33. Bozdağ, A.; Yavuz, F.; Günay, A.S. AHP and GIS based land suitability analysis for Cihanbeyli (Turkey) county. Environ. Earth Sci. 2016, 75, 1-15. [CrossRef]

34. Liu, Y.; Deng, W.; Song, X.Q. Relief degree of land surface and population distribution of mountainous areas in china. J. Mt. Sci. 2015, 12, 518-532. [CrossRef]

35. Elena Arce, M.; Saavedra, Á.; Míguez, J.L.; Granada, E. The use of grey-based methods in multi-criteria decision analysis for the evaluation of sustainable energy systems: A review. Renew. Sustain. Energy Rev. 2015, 47, 924-932. [CrossRef]

36. Yang, F.; Zeng, G.; Du, C.; Tang, L.; Zhou, J.; Li, Z. Spatial analyzing system for urban land-use management based on GIS and multi-criteria assessment modeling. Prog. Nat. Sci. 2008, 18, 1279-1284. [CrossRef]

37. Kuo, Y.; Yang, T.; Huang, G.W. The use of grey relational analysis in solving multiple attribute decision-making problems. Comput. Ind. Eng. 2008, 55, 80-93. [CrossRef]

38. Widiatmaka; Ambarwulan, W.; Setiawan, Y.; Walter, C. Assessing the suitability and availability of land for agriculture in Tuban Regency, East Java, Indonesia. Appl. Environ. Soil Sci. 2016, 2016, 1-13. [CrossRef]

39. Ma, H.; Zhou, Z.; Wu, C.; Wei, H.; Liu, X.; Tang, W. Forestland suitability evaluation and forest category structure adjustment in Xishui County based on GIS. Soil Water Conserv. China 2011, 3, 44-47. (In Chinese)

40. Zhang, X.; Fang, C.; Wang, Z.; Ma, H. Urban construction land suitability evaluation based on improved multi-criteria evaluation based on GIS (MCE-GIS): Case of new Hefei City, China. Chin. Geogr. Sci. 2013, 23, 740-753. [CrossRef]

41. Liu, S.; Zhao, Q.; Wen, M.; Deng, L.; Dong, S.; Wang, C. Assessing the impact of hydroelectric project construction on the ecological integrity of the Nuozhadu Nature Reserve, southwest China. Stoch. Environ. Res. Risk Assess. 2013, 27, 1709-1718. [CrossRef]

42. Akinci, H.; Özalp, A.Y.; Turgut, B. Agricultural land use suitability analysis using GIS and AHP technique. Comput. Electron. Agric. 2013, 97, 71-82. [CrossRef] 
43. Tong, O.; Shao, S.; Zhang, Y.; Chen, Y.; Liu, S.L.; Zhang, S.S. An AHP-based water-conservation and waste-reduction indicator system for cleaner production of textile-printing industry in China and technique integration. Clean Technol. Environ. Policy 2012, 14, 857-868. [CrossRef]

44. Fei, D.; Li, X.B.; Hong, W.; Meng, Z.; Li, R.H.; Xu, L. GIS-based assessment of land suitability for Alfalfa cultivation: A case study in the dry continental steppes of northern China. Span. J. Agric. Res. 2014, 12, 364.

45. Zhang, B.; Gao, J.X.; Xie, G.D.; Lu, C.X. Forest soil conservation based on eco-service provision unit method and its value in Anji County, Huzhou, Zhejiang, China. J. For. Res. 2015, 26, 405-415. [CrossRef]

46. Zhang, B.; Li, W.H.; Xie, G.D.; Xiao, Y. Water conservation of forest ecosystem in Beijing and its value. Ecol. Econ. 2010, 69, 1416-1426.

47. Wang, X.; Bennett, J. Policy analysis of the conversion of cropland to forest and grassland program in China. Environ. Econ. Policy Stud. 2008, 9, 119-143. [CrossRef]

48. Rozelle, S. Grain for green: Cost-effectiveness and sustainability of China's conservation set-aside program. Land Econ. 2003, 81, 247-264.

49. Administration, S.F. China Forestry Statistical Yearbook; Chinese Forestry Press: Beijing, China, 2015. (In Chinese)

50. Morri, E.; Pruscini, F.; Scolozzi, R.; Santolini, R. A forest ecosystem services evaluation at the river basin scale: Supply and demand between coastal areas and upstream lands (Italy). Ecol. Ind. 2014, 37, 210-219. [CrossRef]

51. Gao, R. Water balance of major forest types in east Liaoning mountainous region. Bull. Soil Water Conserv. 2002, 22, 5-8. (In Chinese)

52. Xue, D.; Tisdell, C. Valuing ecological functions of biodiversity in Changbaishan Mountain biosphere reserve in northeast China. Biodivers. Conserv. 2001, 10, 467-481. [CrossRef]

53. Guo, Z.; Xiao, X.; Gan, Y.; Zheng, Y. Ecosystem functions, services and their values-A case study in Xingshan County of China. Ecol. Econ. 2001, 38, 141-154. [CrossRef]

54. Ouyang, Z.; Wang, X.; Miao, H. A primary study on Chinese terrestrial ecosystem services and their ecological-economic values. Acta Ecol. Sin. 1999, 19, 607-613. (In Chinese)

55. Sun, X.; Xie, G.; Cheng, S.; Xiao, Y.; Lu, C. Services for soil conservation and its monetary value of Chinese cropping system. J. Soil Water Conserv. 2005, 19, 156-159. (In Chinese)

56. Lu, S.; Jin, F.; Yu, X.; Xie, Y.; Li, Y.; Wang, S. The evaluation of soil conservation of forest ecosystem in China. Sci. Soil Water Conserv. 2005, 3, 16-21. (In Chinese)

57. Jia, W. Soil in Liaoning Province; Liaoning Science and Technology Press: Shenyang, China, 1992. (In Chinese)

58. Sun, X.; Zhou, H.; Xie, G. Ecological services and their values of Chinese agroecosystem. China Popul. Resour. Environ. 2007, 17, 55-60. (In Chinese)

59. Ninan, K.; Inoue, M. Valuing forest ecosystem services: Case study of a forest reserve in Japan. Ecosyst. Serv. 2013, 5, 78-87. [CrossRef]

60. Yang, Z.; Zheng, D.; Wen, H. Studies on service value evaluation of agricultural ecosystem in Beijing region. J. Nat. Resour. 2005, 20, 564-571. (In Chinese).

61. Jim, C.; Chen, W.Y. Assessing the ecosystem service of air pollutant removal by urban trees in Guangzhou (China). J. Environ. Manag. 2008, 88, 665-676. [CrossRef] [PubMed]

62. Daily, G.C.; Polasky, S.; Goldstein, J.; Kareiva, P.M.; Mooney, H.A.; Pejchar, L.; Ricketts, T.H.; Salzman, J.; Shallenberger, R.; Ruffo, S. Ecosystem services in decision making: Time to deliver. Front. Ecol. Environ. 2009, 7, 21-28. [CrossRef]

63. Blaen, P.J.; Jia, L.; Peh, K.S.; Field, R.H.; Balmford, A.; Macdonald, M.A.; Bradbury, R.B. Rapid assessment of ecosystem services provided by two mineral extraction sites restored for nature conservation in an agricultural landscape in eastern England. PLoS ONE 2015, 10, e0121010. [CrossRef] [PubMed]

64. Lei, K.; Pan, H.Y.; Lin, C.Y. A landscape approach towards ecological restoration and sustainable development of mining areas. Ecol. Eng. 2016, 90, 320-325. [CrossRef]

65. Maczkowiack, R.I.; Smith, C.S.; Slaughter, G.J.; Mulligan, D.R.; Cameron, D.C. Grazing as a post-mining land use: A conceptual model of the risk factors. Agric. Syst. 2012, 109, 76-89. [CrossRef]

66. Baja, S.; Chapman, D.M.; Dragovich, D. Spatial based compromise programming for multiple criteria decision making in land use planning. Environ. Model. Assess. 2007, 12, 171-184. [CrossRef]

67. Zipper, C.E.; Burger, J.A.; Evans, D.M.; Donovan, P. Young forest composition and growth on a reclaimed Appalachian coal surface mine after nine years. J. Am. Soc. Min. Reclam. 2012, 1, 56-84. [CrossRef] 
68. Simmons, J.A.; Currie, W.S.; Eshleman, K.N.; Kuers, K.; Monteleone, S.; Negley, T.L.; Pohlad, B.R.; Thomas, C.L. Forest to reclaimed mine land use change leads to altered ecosystem structure and function. Ecol. Appl. 2008, 18, 104-118. [CrossRef] [PubMed]

69. Sena, K.; Barton, C.; Hall, S.; Angel, P.; Agouridis, C.; Warner, R. Influence of spoil type on afforestation success and natural vegetative recolonization on a surface coal mine in Appalachia, United States. Restor. Ecol. 2015, 23, 131-138. [CrossRef]

70. Miao, Z.; Marrs, R. Ecological restoration and land reclamation in open-cast mines in Shanxi Province, China. J. Environ. Manag. 2000, 59, 205-215. [CrossRef]

71. Ruiz Ballesteros, E.; Hernández Ramírez, M. Identity and community-Reflections on the development of mining heritage tourism in southern Spain. Tour. Manag. 2007, 28, 677-687. [CrossRef]

72. Zhang, J.; Fu, M.; Hassani, F.P.; Hui, Z.; Geng, Y.; Bai, Z. Land use-based landscape planning and restoration in mine closure areas. Environ. Manag. 2011, 47, 739-750. [CrossRef] [PubMed]

2017 by the authors. Licensee MDPI, Basel, Switzerland. This article is an open access article distributed under the terms and conditions of the Creative Commons Attribution (CC BY) license (http://creativecommons.org/licenses/by/4.0/). 